\title{
The influence of microclimate conditions on ozone disinfection efficacy in working places
}

\author{
Concetta Pironti $^{1,2} \cdot$ Giuseppina Moccia $^{1,2} \cdot$ Oriana Motta ${ }^{1,2}$ (D) Giovanni Boccia ${ }^{1,2} \cdot$ Gianluigi Franci $^{1,2}$. \\ Emanuela Santoro ${ }^{1} \cdot$ Mario Capunzo $^{1,2} \cdot$ Francesco De Caro $^{1,2}$
}

Received: 30 April 2021 / Accepted: 9 July 2021 / Published online: 27 July 2021

(C) The Author(s) 2021

\begin{abstract}
In recent years, the sanitization of environments, devices, and objects has become mandatory to improve human and environmental safety, in addition to individual protection and prevention measures. International studies considered ozone one of the most useful and easy sanitization methods for indoor environments, especially hospital environments that require adequate levels of disinfection. The purpose of this work was to evaluate the microclimate influence on sanitizing procedure for indoor settings with ozone, to prevent infections and ensure the safe use of the environments. The concentration of ozone was measured during sanitization treatment and estimation of microorganisms' survival on the air and different contaminated plates after the sanitization operations were performed. The results demonstrated a significant reduction in the microbial count that always fell below the threshold value in different conditions of distance, temperature, and relative humidity.
\end{abstract}

Keywords Ozone $\cdot$ Disinfection $\cdot$ Health safety $\cdot$ Indoor environments $\cdot$ Microclimate conditions

\section{Introduction}

In the last year, a new worldwide emergency introduced the requirement of new disinfection and sanitation procedures to optimize the quality of care and work safety in professional environments [Amato et al. 2020; Brunetti et al. 2006, 2008; Esposito et al. 2017; Fraise 1999; Gilbert and McBain 2003; Hoy 1981; Jakobsson et al. 1991; Moccia et al. 2020a; Motta et al. 2008, 2015, 2018; Pitten et al. 2003; Pironti et al. 2021; Proto et al. 2016; Sauerbrei et al. 2012]. In particular, ozone-producing devices were used as the easiest and most efficacious disinfection and sanitization method to prevent the spread of multiresistant microorganisms in hospital wards [Knobler et al. 2004; Food and drug administration 1982;

\section{Responsible Editor: Lotfi Aleya}

Oriana Motta

omotta@unisa.it

1 Department of Medicine Surgery and Dentistry "Scuola Medica Salernitana", University of Salerno, via S. Allende 1, 84081 Baronissi, SA, Italy

2 AUO San Giovanni di Dio e Ruggi d'Aragona Hospital, via S. Leonardo, Salerno, Italy
Rubio-Romero et al. 2020; Moccia et al. 2020b; Sousa et al. 2011]. The high efficiency of ozone was evaluated against many microorganisms, fungi and viruses both on the surfaces and suspended in the air [Dubuis et al. 2020] and, for this reason, was also validated by many international organizations [Environmental Protection Agency 2020]. The use of ozone was associated with its properties: high oxidizing power towards all types of organic and inorganic compounds; complete inactivation of microorganisms that can be present on the surfaces but also under the surfaces of furniture; great sanitizing power for the air. However, only a few recent studies investigated the relationship between ozone concentration and microclimate conditions of different environments [Blanco et al. 2021]. Some experiments demonstrated that the ozone concentration and the relative humidity values played an important role in the efficiency of ozone and its antimicrobial effect [Grignani et al. 2021]. Hudson evaluated the effect of concentration, time of exposure, and relative humidity on 12 viruses. The results of this work showed a reduction of three orders of magnitude, with respect to the initial virus title, at a concentration of $25 \mathrm{ppm}$ of ozone for $15 \mathrm{~min}$ exposure at $>90 \%$ RH [Hudson et al. 2009]. Although this could be considered an encouraging result, the ozone concentration used in the experiment is very high and its oxidizing effects could be risky for operators and environments with degradation of 
several materials. The right compromise should be to find the optimal dose and time of usage sufficient to destroy microorganisms with the least degradation effects on materials and impairment to human health. Moreover, US EPA studies highlighted the correlation between human exposure and ozone-induced decreases in lung function and inflammation in healthy, exercising adults at concentrations as low as $60 \mathrm{ppb}$ after $6.6 \mathrm{~h}$ of exposure [Environmental Protection Agency 2020]. The available epidemiologic evidence suggests detrimental health effects such as inhalation toxicity, skin corrosion and serious eye damage on exposure to even low doses of ozone [Jaffe 1967; Lee et al. 1996; Salvador et al. 2019].

Although the biocidal efficiency of ozone was investigated in different conditions, studies for its use in indoor environments (not laboratory scale) are missing, and this aspect has to be necessarily improved to avoid misleading circumstances that could cause considerable outbreaks. An efficient disinfection process with ozone could be obtained through the good distribution of gas in large areas, no stagnant regions with lower ozone concentrations and a circulating fan to ensure a uniform flow through the entire room during sanitization. Moreover, utilization of the right dose in different conditions is fundamental since low concentrations and time of exposure are unlikely to be effective in sanitization, and inefficient disinfection would represent an additional risk to people that could reduce their personal protection feeling safe [Motta et al. 2021]. The advantages of ozone over traditional disinfectants are related to low costs, easy production and use, no disinfection residues, and its capability as gas to penetrate each part of a room. Our work analyzed the effects of environmental conditions such as temperature, humidity, and the distance from the ozone-generator on the decontamination of air and surfaces in a healthcare office and a classroom occupied and unoccupied by students.

\section{Materials and methods}

Ozone was generated in-situ using a portable commercial ozone-generating apparatus, with an average production of $1.6 \mathrm{ppm} / \mathrm{h}$. The generator is equipped with a device that guarantees a total reduction of ozone concentration at the end of the treatment. Automatically, as described by the suppliers, at the end of the ozonation phase, the catalyzing phase begins. During this latter, the residual ozone in the air passes through the UV-C lamps, which converts ozone into oxygen eliminating any residue.

Ozone concentration was evaluated by means of Airnova sensors, calibrated and certified by the suppliers. In Fig. 1, the curves of ozone concentration during sanitization until the disappearance after $70 \mathrm{~min}$ are reported. The maximum value obtained was $4.80 \mathrm{ppm}$ after $20 \mathrm{~min}$ and the average value was $1.6 \mathrm{ppm}$ for the entire ozone-generation time. The ozone

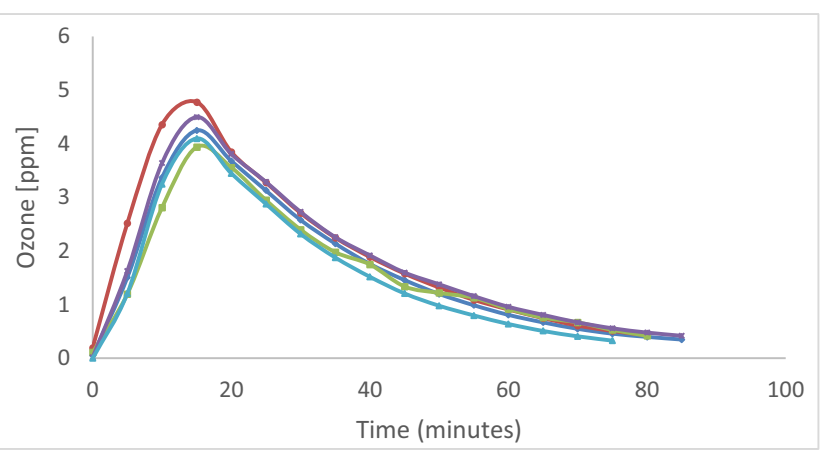

Fig. 1 Ozone concentration in ppm evaluated at $1 \mathrm{~m}$ red, $2 \mathrm{~m}$ blue, $3 \mathrm{~m}$ light blue, $5 \mathrm{~m}$ violet, $12 \mathrm{~m}$ green

concentration was measured in different points of the room in comparison with the position of the generator and the curves showed represent the measurements performed. Two different kinds of rooms were analysed: a $150 \mathrm{~m}^{2}$ classroom (volume of $600 \mathrm{~m}^{3}$ ) with and without students, and a healthcare office of about $60 \mathrm{~m}^{2}$, with a volume of $180 \mathrm{~m}^{3}$ (ozonation was always conducted in the absence of people).

The plates used for the microbial count were contaminated with representative gram-negative E. coli (ATCC 25922) bacteria, reconstituted from a deep-frozen stock (storage at $-80^{\circ}$ C). After lightly scratching the surface of the frozen stock by a sterile inoculating loop, bacterial cultures were suspended in Luria-Bertani liquid medium (LB) using a vortex mixer and grown in a shaking incubator at $37^{\circ} \mathrm{C}$ for $12 \mathrm{~h}$, which lead to a cell density of approximately $1 \times 10^{9} \mathrm{CFU} / \mathrm{mL}$. Bacterial growth was verified by measuring the optical density (OD at $600 \mathrm{~nm}$; OD600) of two 1:10 diluted aliquots by spectrophotometry (Thermo Spectronic, He $\lambda$ ios $\gamma$ ). The calibration showed the linear association of the optical density at $600 \mathrm{~nm}(\mathrm{OD} 600) \mathrm{vs} \mathrm{CFU} / \mathrm{mL}$ values for the tested bacterial strain. The plates were then exposed at an average concentration of $1.6 \mathrm{ppm}$ ozone for $70 \mathrm{~min}$ at temperatures 16, 21 and $25^{\circ} \mathrm{C}$ and relative humidity of 35,45 and $55 \%$. In each experiment, plates placed for $70 \mathrm{~min}$ without ozone exposure were used as controls. The plates were positioned at a different distance from the ozone generator at 1, 1.5, 2, 3, 5 and $12 \mathrm{~m}$ on the same level and 1 and $2 \mathrm{~m}$ in height.

Air samples were collected by SAS 180 S (SURFACE AIR SYSTEM monitoring instruments) system for microbiological environmental monitoring, used in combination with contact plates. The instrument was positioned one/two meters from the ozonization system, which was calibrated to start measurement after $5 \mathrm{~min}$ to eliminate interferences of operators in the room and sampling $1000 \mathrm{~L}$ of air in $6 \mathrm{~min}$. The measurements were done before, during, and after ozone treatments. Microbiological analyses in the air were performed using a $24 \mathrm{~cm}^{2}$ Rodac (Replicate Organism Direct Agar Contact) plate with a PCA (plate count agar to total microbial count) substrate, specific for the monitoring of environment hygiene (air and surface). The plates were incubated under aerobic 
conditions at $30{ }^{\circ} \mathrm{C}$ for $48 \mathrm{~h}$. The number of microorganisms per plate (CFU) was calculated from the number of colonies obtained on the plates containing less than 300 colonies/plate.

\section{Results and discussions}

The influence of microclimate conditions on the efficiency of ozone as a sanitation system is shown in Tables 1-2 that summarize the results of the measurements in the office.

The results reported in the tables show that the ozone sanitization system succeeds to eliminate about $90 \%$ of the microorganisms present on the analyzed plates in different conditions of distance, and relative humidity. Different temperatures were also tested but the results were comparable and it was not considered useful to report them.

The choice to work at low ozone concentration was related to the awareness of the dangerous effects on rubber and metals at high concentrations, due to its oxidizing power. Limited studies evaluated the progressive damage of materials and products, shortening their life with significant economic losses for industries and other activities [Lee et al. 1996; California Environmental Protection Agency 2020]. The reduction of ozone concentration is necessary to avoid consequences on materials (rubber, nylon, acetate, metals, etc.), human and environmental safety [James 1985]. For this reason, a high concentration could be used in critical environments and circumstances only for short periods. In previous studies, the total ozone dose was considered an important factor for biocidal activity and it is calculated as the product of exposure time and concentration [Dennis et al. 2020]. Tseng and Li 2008 reported that the required ozone dosage for $99 \%$ viral inactivation should be calculated as ppm $\times$ minutes (i.e. product of ozone gas concentration multiplied by duration). To inactivate (99\% reduction) dsDNA(T7) virus $114 \mathrm{~min}[\mathrm{ppm}]$ is required at $55 \%$ relative humidity and even lower for other viruses $(37.99,30$ for $\phi x 174$, MS2, $\phi 6$ respectively). In our case, we always obtained a value of $112 \mathrm{~min}[\mathrm{ppm}]$ by calculating the average concentration (1.6 $\mathrm{ppm}$ ) and the duration of exposure (70 min), very close to the value suggested by Tseng and $\mathrm{Li}$ to inactivate viruses. In all experiments, we obtained a significant reduction of microbial load, demonstrating the effectiveness for all environmental conditions analyzed. In fact, independently of the distance, height, temperature, and $\mathrm{RH}$, we found rather low contamination on the plates compared to the control where a $6.8 * 10^{6}$ $\mathrm{CFU} /$ plate was observed on average. The concentration of ozone used permits obtaining a good balance between microbial load reduction and reduced damage on materials in the healthcare office.

In Fig. 2, the microbial load determined after ozone disinfection at different distances and heights is reported. It can be observed that the concentration of microorganisms decreased equally following exposure to ozone at different distances. The results are in agreement with those reported by Zucker et al. 2021 which were done in a reaction chamber equipped with a miniature table and cabinet to simulate indoor contamination.

In Fig. 1, the ozone concentration measured in various points of the room is reported, and we can observe an equal distribution of gas in the environment with the ozone concentration showing the same trend for all the positions analysed. The ozone concentration reaches a maximum value of $4.80 \mathrm{ppm}$ after $20 \mathrm{~min}$ and the complete disappearance after $70 \mathrm{~min}$. Although there is a natural ozone reduction in the air, a faster residual ozone removal can be achieved by using adsorbents and/or catalytic converters, as in this case. This is an interesting and unprecedented evidence of the ozone disinfection potential because in real indoor environments, it is possible to disinfect surfaces not typically disinfected with manually applied liquid disinfectants, such as the back of plane seats or the top of furniture. However, the correct use of ozone is related to many factors, i.e. ozone concentration, the temperature of the environment, humidity of the environment and exposure time. For these reasons, we have tested the efficiency of ozone disinfection with different conditions of temperature and humidity, as reported by results in Table 2 . Chun-Chieh and Chih-Shan (2006) reported the 90\% and 99\%
Table 1 Microbial load (CFU/ plate) estimated on plates exposed at different distances and heights (results are averaged on 10 measurements)

\begin{tabular}{lllllll}
\hline $\begin{array}{l}\text { Distance of plates from generator } \\
(\mathbf{m})\end{array}$ & $\begin{array}{l}\text { Post } \\
\text { treatment } \\
\text { (CFU/mL) }\end{array}$ & sd & $\begin{array}{l}\text { Post } \\
\text { treatment } \\
\text { (CFU/mL) }\end{array}$ & sd $\begin{array}{l}\text { Post } \\
\text { treatment } \\
\text { (CFU/mL) }\end{array}$ & sd \\
& Floor level & & $\mathbf{1}$ height & 2 m height & \\
\hline 1 & 15 & \pm 3 & 25 & \pm 5 & 23 & \pm 2 \\
1.5 & 20 & \pm 2 & 17 & \pm 1 & 25 & \pm 2 \\
2 & 22 & \pm 3 & 19 & \pm 4 & 26 & \pm 2 \\
3 & 20 & \pm 2 & 23 & \pm 1 & 16 & \pm 2 \\
5 & 17 & \pm 1 & 26 & \pm 1 & 22 & \pm 1 \\
12 & 24 & \pm 1 & 31 & \pm 4 & 27 & \pm 2 \\
\hline
\end{tabular}


Table 2 Microbial load (CFU/ plate) estimated on plates exposed at different distances and different values of RH (results are averaged on 10 measurements)

\begin{tabular}{lllllll}
\hline $\begin{array}{l}\text { Distance of plates from generator } \\
(\mathbf{m})\end{array}$ & $\begin{array}{l}\text { Post } \\
\text { treatment } \\
(\mathbf{C F U} / \mathbf{m L})\end{array}$ & sd & $\begin{array}{l}\text { Post } \\
\text { treatment } \\
\text { (CFU/mL) }\end{array}$ & sd $\begin{array}{l}\text { Post } \\
\text { treatment } \\
\text { (CFU/mL) }\end{array}$ & sd \\
& $\mathbf{3 5 \%} \mathbf{R H}$ & & $\mathbf{4 5 \%} \mathbf{R H}$ & & $\mathbf{5 5 \%} \mathbf{R H}$ & \\
\hline 1 & 16 & \pm 3 & 19 & \pm 5 & 15 & \pm 2 \\
1.5 & 22 & \pm 2 & 18 & \pm 1 & 25 & \pm 3 \\
2 & 24 & \pm 1 & 25 & \pm 4 & 26 & \pm 2 \\
3 & 18 & \pm 1 & 25 & \pm 1 & 23 & \pm 2 \\
5 & 21 & \pm 1 & 26 & \pm 3 & 23 & \pm 1 \\
12 & 32 & \pm 3 & 30 & \pm 2 & 27 & \pm 2 \\
\hline
\end{tabular}

inactivation of four different viruses, representative of ssDNA, ssRNA, dsDNA, and enveloped dsRNA categories and the ozone concentration required for the same inactivation level was lower at $85 \% \mathrm{RH}$ than at $55 \%$. The humidity is an important parameter to take into consideration because, under rather dry environmental conditions, the disinfection procedure could require considerably longer exposure times. In fact, microorganisms die more rapidly with increased humidity that favours the formation of radicals. Most of the studies reported in the literature have regarded the analysis of environmental conditions simulated in the laboratory in small chambers or cabinets with experimental conditions, in terms of temperature and relative humidity, set to room temperature and relative humidity $>55 \%$. Yano et al. 2020 described the inactivation of SARS-CoV-2 by gaseous ozone treatment using a concentration of $1.0 \mathrm{ppm}$ ozone for $60 \mathrm{~min}$ and $6.0 \mathrm{ppm}$ of ozone at $55 \mathrm{~min}$ at room temperature, $25^{\circ} \mathrm{C}$, and relative humidity of 60-80\%. An important reduction was obtained after exposure of $6.0 \mathrm{ppm}$ ozone at $55 \mathrm{~min}$, from $2.0^{*} 10^{6} \mathrm{pfu} / \mathrm{mL}$ to $1.0 * 10^{3} \mathrm{pfu} / \mathrm{mL}$. Ozone gas was also effective against a pseudovirus at short contact times, below $30 \mathrm{~min}$, as reported by Zucker et al. 2021 in their work. A recent study demonstrated also the efficacy of air treatment for phage and MNV-1 (eukaryotic murine norovirus) inactivation using low ozone

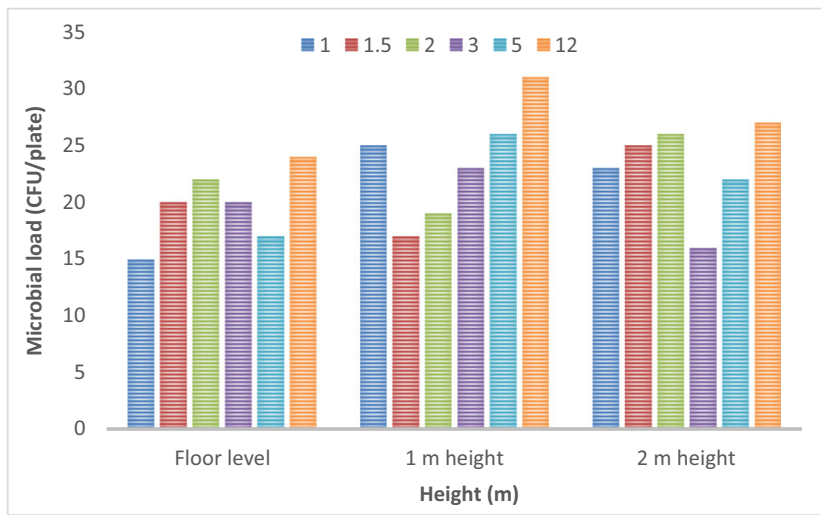

Fig. 2 Evaluation of Microbial load estimated after ozone disinfection at different distances and heights from the ozone generator concentrations, $1.13 \mathrm{ppm} \pm 0.26 \mathrm{ppm}$ and $0.23 \mathrm{ppm} \pm 0.03$ ppm, respectively, at various relative humidity levels and exposure times of up to $70 \mathrm{~min}$. The inactivation of $\varphi \mathrm{X} 174$, MS2 (phages) and MNV-1 was obtained with an exposure of $40 \mathrm{~min}$ at $85 \%$ relative humidity; while for other phages (PR772 and $\varphi 6$ ) exposure for 10 min was enough [Dubuis et al. 2020].

Although in our working conditions, similar to daily use in healthcare facilities, we did not test the antiviral action on pathogenic viruses nor their surrogates, we analyzed the ozone efficacy on a selected gram-negative bacterium, used as an indicator of microbial contamination, in a real environment and we noticed no significant differences in bacterial inactivation between $35-55 \% \mathrm{RH}$ and a temperature range $16-25^{\circ}$ $\mathrm{C}$ with an ozone concentration of $1.6 \mathrm{ppm}$ for $70 \mathrm{~min}$.

In Table 3, we report the results obtained in the air and on surfaces in a classroom that was used or not by students (ozonation was always conducted in the absence of people). In the presence of people, both air and surfaces were more contaminated before the ozone treatment and we observed a $90 \%$ microbial load reduction in the air (from $100 \mathrm{CFU} /$ plate to $11 \mathrm{CFU} /$ plate), while in the absence of people starting from a cleaner condition, the complete destruction of microorganisms was obtained. Microbiological analysis of the surfaces showed very good results, unregarding the presence of people. For these experiments, SAS instrument for air control was

Table 3 Total microbial load estimated on sampling performed on different surfaces $(\mathrm{CFU} /$ plate $)$ and in the air $\left(\mathrm{CFU} / \mathrm{m}^{3}\right)$ in a classroom (results are averaged on 10 measurements)

\begin{tabular}{lll}
\hline AIR and surface analysed & $\begin{array}{l}\text { (PCA)* } \\
\text { Pre-treatment }\end{array}$ & $\begin{array}{l}\text { (PCA)* } \\
\text { Post-treatment }\end{array}$ \\
\hline Air & $10 \pm 1$ & - \\
Air with people & $100 \pm 4$ & $11 \pm 2$ \\
Surfaces & $14 \pm 1$ & $3 \pm 1$ \\
Surfaces with people & $36 \pm 1$ & $2 \pm 1$ \\
\hline
\end{tabular}

*Plate count agar 
positioned in the middle of the classroom and three ozone-generators were positioned at the sides of the triangular room to guarantee the right concentration of ozone in all parts of the room and swabs were performed randomly on desks that had been previously used by the students to control the surfaces. Moreover surfaces were analysed also in the absence of students and normal environmental contamination was observed before sanification. In these cases, the environmental conditions were set to $\mathrm{T}=25^{\circ} \mathrm{C}$ and $\mathrm{RH}$ ranged between 45 and $55 \%$. No differences were observed in ozone efficacy in these circumstances.

\section{Conclusions}

Our study aims to define the efficacy and the optimization of ozone concentration achievable in real environments, such as offices and classrooms. These data could be used to lay the groundwork of sanification in defined ambients. In detail, this study provides an analysis of the microclimate influence on ozone efficacy in indoor environments. Different conditions of temperature, relative humidity, and distance from the ozone generator do not affect the reduction of microbial load and the commercial machine used provides a good diffusion of the gas during the sanitization operations. This permits the elimination and inactivation of microbial airborne species and also those that can be present on and under surfaces. The concentration of ozone was also evaluated after the sanitization process to ensure the total reduction of ozone at the end of the treatment, because of environmental/occupational hazard concerns. As already stated in the literature, the important factor for the inactivation of microorganisms is the total ozone dose which is calculated as the product of exposure time and concentration. According to literature data and close to the value suggested, our results pointed to the total dose of $112 \mathrm{~min}$ [ppm] for the sanification of the environments. These data can be used for reducing ozone concentration although assuring safe disinfection under different conditions.

Author contribution Conceptualization O.M., F.DC, C.P., G.M. Data curation C.P., Formal analysis C.P., E.S. Funding acquisition FDC, MC, GB, O.M. Investigation C.P., G.M. Supervision and Validation G. F., F.DC, O.M, M.C., G.B. Visualization C.P., G.M., O.M, E.S., G.F., F. DC, M.C., G.B. Writing Original Draft. C.P. Writing-review and editing C.P., O.M.

Funding Open access funding provided by Università degli Studi di Salerno within the CRUI-CARE Agreement. This work was financially supported by Fondi di Ateneo per la Ricerca di Base (FARB 2020) University of Salerno.

Data and materials availability Not applicable

\section{Declarations}

Ethics approval and consent to participate Not applicable

Consent for publication Not applicable

Competing interests The authors declare no competing interests.

Open Access This article is licensed under a Creative Commons Attribution 4.0 International License, which permits use, sharing, adaptation, distribution and reproduction in any medium or format, as long as you give appropriate credit to the original author(s) and the source, provide a link to the Creative Commons licence, and indicate if changes were made. The images or other third party material in this article are included in the article's Creative Commons licence, unless indicated otherwise in a credit line to the material. If material is not included in the article's Creative Commons licence and your intended use is not permitted by statutory regulation or exceeds the permitted use, you will need to obtain permission directly from the copyright holder. To view a copy of this licence, visit http://creativecommons.org/licenses/by/4.0/.

\section{References}

Amato A, Caggiano M, Amato M, Moccia G, Capunzo M, De Caro F (2020) Infection control in dental practice during the covid-19 pandemic. Int J Environ Res Public Health 17(13):1-12

Blanco A, de Borja OF, Clavo B, Negro C (2021) Ozone potential to fight against SAR-COV-2 pandemic: facts and research needs. Environ Sci Pollut Res Int 28(13):16517-16531. https://doi.org/10.1007/ s11356-020-12036-9

Brunetti L, Santoro E, Cavallo P, Boccia G, Motta O, Capunzo M (2006) Two-years surveillance of fungal contamination in three hospital departments in Campania region J. Prev Med Hyg 47(1):22-25

Brunetti L, De Caro F, Boccia G, Cavallo P, Capunzo M (2008) Surveillance of nosocomial infections: a preliminary study on yeast carriage on hands of healthcare workers. Journal of Preventive Medicine and Hygiene 49(2):63-68

California Environmental Protection Agency (2020) Available online: https://ww2.arb.ca.gov/sites/default/files/2017-10/ozone-fs.pdf. Accessed 20 Nov 2020

Chun-Chieh T, Chih-Shan Li (2006) Ozone for inactivation of aerosolized bacteriophages, aerosol. Sci Technol 40(9):683-689. https:// doi.org/10.1080/02786820600796590

Dennis R, Cashion A, Emanuel S, Hubbard D (2020) Ozone gas: scientific justification and practical guidelines for improvised disinfection using consumer-grade ozone generators and plastic storage boxes. The Journal of Science and Medicine 2:1-15

Dubuis ME, Dumont-Leblond N, Lalibertè C, Veillette M, Turgeon N, Jean J, Duchaine X (2020) Ozone efficacy for the control of airborne viruses: Bacteriophage and norovirus models. PLoS One 15: e0231164. https://doi.org/10.1371/journal.pone.0231164

Environmental Protection Agency (EPA) (2020) USEPA Integrated Science Assessment for Ozone and Related Photochemical oxidant (Final Report). U.S., Environmental Protection Agency, Washington, DC

Esposito S, De Simone G, Gioia R et al (2017) Deep tissue biopsy vs. superficial swab culture, including microbial loading determination, in the microbiological assessment of Skin and Soft Tissue Infections (SSTIs). J Chemother 29(3):154-158

Food and drug administration (1982) GRAS status of ozone. Fed Regist 47:50209

Fraise AP (1999) Choosing disinfectants. J Hosp Infect 43:255-264 
Gilbert P, McBain AJ (2003) Potential impact of increased use of biocides in consumer products on prevalence of antibiotic resistance. Clin Microbiol Rev 16:189-208

Grignani E, Mansi A, Cabella R, Castellano P, Tirabasso A, Sisto R, Spagnoli M, Fabrizi G, Frigerio F, Tranfo G (2021) Safe and effective use of ozone as air and surface disinfectant in the conjuncture of Covid-19. Gases. 1(1):19-32. https://doi.org/10.3390/ gases 1010002

Hoy RH (1981) Accidental systemic exposure to sodium hypochlorite (Clorox) during hemodialysis. Am J Hosp Pharm 8:1512-1514

Hudson JB, Sharma M, Vimalanathan S (2009) Development of a practical method for using ozone gas as a virus decontaminating agent. Ozone Sci Eng 31:216-223

Jaffe LS (1967) The effect of photochemical oxidants on materials. Journal Air Pollution Control Association 17:2047-2055

Jakobsson SW, Rajs J, Jonsson JA, Persson H (1991) Poisoning with sodium hypochlorite solution. Report of a fatal case, supplemented with an experimental and clinico-epidemiological study. Am J Forensic Med Pathol 12:320-327

James RD (1985) Ozone: the intractable problem. Western Association for Art Conservation (WAAC) Newsletter, Alaska

Knobler S, Mahmoud A, Lemon S, Mack A, Sivitz L, Oberholtzer K (2004) Learning from SARS: preparing for the next disease outbreak. National Academies Press, Washington, DC

Lee DS, Holland MR, Falla N (1996) The potential impact od ozone on materials in the UK. Atmos Environ 30:1053-1065

Moccia G, De Caro F, Pironti C, Boccia G, Capunzo M, Borrelli A, Motta O (2020b) Development and improvement of an effective method for air and surfaces disinfection with ozone gas as a decontaminating agent. Medicina 2020b(56):578. https://doi.org/10.3390/ medicina56110578

Moccia G, Motta O, Pironti C, Proto A, Capunzo M, De Caro F (2020a) An alternative approach for the decontamination of hospital settings. Journal of Infection Public Health 13:2038-2044. https://doi.org/10. 1016/j.jiph.2020.09.020

Motta O, Capunzo M, De Caro F, Brunetti L, Santoro E, Farina A, Proto A (2008) New approach for evaluating the public health risk of living near a polluted river. J Prev Med Hyg 49:79-88

Motta O, Zarrella I, Cucciniello R, Vigliotta G, Proto A (2015) Study of the antibacterial activity in the gas phase of a chemical formulation for household waste management. Lett Appl Microbiol 60:223-228. https://doi.org/10.1111/lam.12360

Motta O, Zarrella I, Cucciniello R, Capunzo M, De Caro F (2018) A new strategy to control the proliferation of microorganisms in solid hospital waste and the diffusion of nosocomial infections. Le Infezioni in Medicina 26(3):210-215

Motta O, Pironti C, Moccia G, De Caro F (2021) The misperception of the use of ozone in the sanitation processes. Environ Sci Pollut Res 28:19537-19538. https://doi.org/10.1007/s11356-021-12994-8

Pironti C, Motta O, Proto A (2021) Development of a new vapour phase methodology for textiles disinfection. Cleaner Engineering and Technology 4C:100170. https://doi.org/10.1016/j.clet.2021.100170

Pitten FA, Werner HP, Kramer A (2003) A standardized test to assess the impact of different organic challenges on the antimicrobial activity of antiseptics. J Hosp Infect 55:108-115

Proto A, Zarrella I, Cucciniello R, Pironti C, De Caro F, Motta O (2016) Bactericidal and fungicidal activity in the gas phase of sodium dichloroisocyanurate (NaDCC). Curr Microbiol 73:287-291. https://doi.org/10.1007/s00284-016-1040-x

Rubio-Romero JC, Pardo-Ferreira MDC, Torrecilla-García JA, CaleroCastro S (2020) Disposable masks: Disinfection and sterilization for reuse, and non-certified manufacturing, in the face of shortages during the COVID-19 pandemic, Safety Science, 129:104830. https:// doi.org/10.1016/j.ssci.2020.104830

Salvador CM, Bekö G, Weschler CJ, Morrison G, Le Breton M, Hallquist M, Ekberg L, Langer S (2019) Indoor ozone/human chemistry and ventilation strategies. Indoor Air 29:913-925

Sauerbrei A, Schacke M, Gluck B, Bust U, Rabenau HF, Wutzler P (2012) Does limited virucidal activity of biocides include duck hepatitis B virucidal action. BMC Infect Dis 12:276

Sousa CS, Torres LM, Azevedo MP, de Camargo TC, Graziano KU, Lacerda RA, Turrini RN (2011) Sterilization with ozone in health care: an integrative literature review. Rev Esc Enferm USP 45: $1243-1249$

Tseng C, Li C (2008) Inactivation of surface viruses by gaseous ozone. J Environ Health 70:56-63

Yano H, Nakano R, Suzuki Y, Nakano A, Kasaharab K, Hoso H (2020) Inactivation of severe acute respiratory syndrome coronavirus 2 (SARS-CoV-2) by gaseous ozone treatment. J Hosp Infect 106: 837-838

Zucker I, Lester Y, Alter J (2021) Pseudoviruses for the assessment of coronavirus disinfection by ozone. Environ Chem Lett 19:17791785. https://doi.org/10.1007/s10311-020-01160-0

Publisher's note Springer Nature remains neutral with regard to jurisdictional claims in published maps and institutional affiliations. 